\title{
Assessing Human Development of Paddy Farmers Compared to Non- Farmers through Indexing of Health, Assets and Education: A Case Study in Kurunegala District of Sri Lanka
}

\author{
D.M.D.K. Dassanayake and N.R. Abeynayake*
}

\begin{abstract}
This paper addresses the methodological issues concerning construction of composite indices to compare human development of farming and non-farming communities in Kurunegala District. Three composite indices were developed separately for two communities with respect to Health, Assets and Education. Similar income groups were considered in order to facilitate the comparison. To develop three indices, the Principal Component Analysis was performed separately for each set of indicators, Health, Assets and Education in paddy farmer and nonfarmer community. The study revealed that all aggregate index values of paddy farmers were lower than those of non-farmer index values in Kurunagala District. The indices developed in the present study would be useful to assess the level of human development in similar occurrences. Further, it highlights that the values of three indices obtained for paddy farmers are generally lower than those of non-farmers in Kurunegala district. The findings based on the indices can be used by the government and policy makers as baseline information to develop programs to uplift the living standards of farmer community.
\end{abstract}

Keywords: Indexing, Non-farmer community, Paddy farmer community

\section{INTRODUCTION}

Paddy sector plays a vital role in the Sri Lankan economy which contributes about 2.9 percent to the total Gross Domestic Product (GDP) of the country (Central Bank Annual Report, 2008).

Department of Agribusiness Management, Faculty of Agriculture and Plantation Management, Wayamba University of Sri Lanka,

Makandura, Gonawila (NWP).

* rabeynayake@hotmail.com
Further, it provides livelihood for over 0.88 million farm families island wide. Out of the total labor force of the country, nearly 32 percent is engaged in agriculture related activities (Department of Census and Statistics, 2008) and the rice sector itself employs almost half of the total agricultural labor force.

Historically, paddy farmers and their households had played a key role in the development efforts in Sri Lanka. As a result, various governments in power, especially in the post-independence era, have offered various incentives and subsidies of different nature to uplift the paddy production of the country (Adhikarinayake, 2005). However, growth of an economy in monetary terms cannot be considered as a reasonable measure to assess the development, because the performance of a community cannot be seen as a mere sum of its economic growth. For example, GDP of a country cannot be considered as a reasonably good measurement to determine the nation's wealth and economic performance over time as it does not capture certain aspects such as health, education and other related socio-economic conditions. In turn, the indices such as Physical Quality of Life Index (PQLI) and Human Development Index (HDI) play a better role in this respect (Shukla and Kakar, 2006). However, estimation of which at the sectoral or community level is complex exercise mainly because of the paucity of data and non-existence of well-defined linkages. Consequently, in recent years, there has been considerable growth in the use of well 
conceptualized aggregates or composite indicators at various levels in order to assess performances between and across countries, in general, and communities and sectors, in particular. The main advantage of developing an index is that it contracts a large number of indicators into a smaller number of "units" that represent the real situation so that the outcome can effectively be used to assess the performance of a given community, district/s, region/s and village/s etc.

According to the concept of human development, improvement in human conditions can be reached by expanding the range of people's choices and enhancing human capabilities. From this standpoint, it is a composite notion, reflecting how health, asset and education relate to the range of community performances at a particular point in time. If there are glaring gaps between communities that are not healthy with respect to their life standards, it is likely to impede the country's overall progress and sustainable development (Kundu et al., 2002).

The purpose of this study was to compare the status of health, assets and education of paddy farmers and those who were not involved mainly with paddy farming (i.e. non-farmers) in the Kurunegala district through indexing. The methods used to develop the index and collect and analyze data are explored next.

\section{METHODOLOGY}

\section{Development of the Index}

Three indices, namely: (1) Heath Index (HI); (2) Asset Index (AI), and (3) Education Index (EI) were developed for each community using Principal Component (PC) analysis for the indicators given in Table 1. Selection criteria of PCs were based on the Eigen values, and in turn, different number of PCs was selected to develop three indices. Different indicators used to develop "Heath", "Asset" and "Education" indices are reported in Table 1.

Cost per calorie $=O P L * C C P I * \frac{1}{N A}$

House hold calorie intake was calculated considering the sex and age. Each set of indicators expressed above can be normalized by subtracting the minimum value of the particular component from its actual value and dividing it by the range, which is the difference between the maximum and minimum value of the selected components by following equation:

$$
\frac{X_{i}-X_{\min }}{X_{\max }-X_{\min }}
$$

Next, a Correlation Matrix R was computed from standardized variables, followed by solving the determinant equation $|R-\lambda I|=0$ for $\lambda$ where $\mathrm{R}$ is an $n \times n$ matrix. This provides an $n^{\text {th }}$ degree polynomial equation in $\lambda$ and hence $k$ roots. These roots are called Eigen Values of Correlation Matrix R. $\lambda$ is arranged in descending order of magnitude, as $\lambda_{1}>\lambda_{2}>\ldots>\lambda_{3}$. Corresponding to each value of $\lambda$, the matrix equation $(R-\lambda I) \alpha=0$ is solved for the $n \times 1$ Eigen Vectors $\alpha$ subject to the condition that $\alpha^{\prime} \alpha=1$ (normalization condition.). The Index is estimated as weighted average of $n$ principal components ( $\mathrm{P}$ 's), where the weights are the Eigen Values of the Correlation Matrix R, and it is known that:

$$
\lambda_{1}=\operatorname{var}\left(P_{1}\right), \lambda_{2}=\operatorname{var}\left(P_{2}\right)=\ldots \ldots . \lambda_{n}=\operatorname{var}\left(P_{n}\right)
$$


Table 1. Summary of Indicators for Health, Asset and Education indices

\begin{tabular}{|c|c|c|}
\hline Index & Indicators & Scale of measurement \\
\hline \multirow[t]{9}{*}{ Health } & Chronic disease & Yes, No \\
\hline & Number of chronic diseases & None, One, Two, More than two \\
\hline & 3. Frequency of getting illness per year & Once, Twice, More than twice \\
\hline & 4. Proportion of immunized children & Immunized \% \\
\hline & 5. Reliable health service & $\begin{array}{l}\text { Government doctors, Rural hospital } \\
\text { doctors, Medical assistants, Other }\end{array}$ \\
\hline & 6. Problems of health service & $\begin{array}{l}\text { Number of problems stated by } \\
\text { respondents }\end{array}$ \\
\hline & 7. Access to safe drinking water & $\begin{array}{l}\text { Government tap line, Own well, Common } \\
\text { well, River/tank }\end{array}$ \\
\hline & $\begin{array}{l}\text { 8. Per head expenditure for health and } \\
\text { medicine }\end{array}$ & \\
\hline & $\begin{array}{l}\text { 9. Percentage of household expenditure for } \\
\text { food and non-alcoholic beverages from } \\
\text { minimum required food and non-alcoholic } \\
\text { beverages }\end{array}$ & *Scale was developed as described below. \\
\hline \multirow{12}{*}{$\begin{array}{l}\text { Household } \\
\text { Asset }\end{array}$} & 1. $\quad$ Push bicycle (PB) & Yes, No \\
\hline & 2. Motor bicycle (NM) & Yes, No \\
\hline & 3. Motor vehicle (CV) & Yes, No \\
\hline & 4. Television (TV) & Yes, No \\
\hline & 5. Computer (CO) & Yes, No \\
\hline & 6. Radio (RA) & Yes, No \\
\hline & 7. Radio cassette player (RC) & Yes, No \\
\hline & 8. Household own refrigerator (RF) & Yes, No \\
\hline & 9. Electric kettle (EK) & Yes, No \\
\hline & 10. Electric iron (EI) & Yes, No \\
\hline & 11. Telephone/cell phone (TP) & Yes, No \\
\hline & 12. Housing condition (HC) & Permanent, Rent, Temporary \\
\hline \multirow[t]{6}{*}{ Education } & 1. Farmer education (passed highest grade) & $\begin{array}{l}\text { Grade } 5 \text {, Grade } 8 \text {, G.C.E. O/L ,G.C.E } \\
\text { A/L }\end{array}$ \\
\hline & $\begin{array}{l}\text { 2. Proportion of schooling children (aged } 5 \\
\text { and above) }\end{array}$ & Percentage of schooling children \\
\hline & 3. Reason for stop schooling & Financial problem, Non-financial problem \\
\hline & Per head expenditure on education & Education expenditure per child \\
\hline & 5. Availability of government schools & Yes, No \\
\hline & 6. Type of school & Government, Semi government, Private \\
\hline
\end{tabular}

* The official poverty line is defined at the per-capita expenditure for a person to be able to meet the Nutritional Anchor (NA) of 2030 kilocalories (Department of Census and Statistics, 2002). The official poverty line (OPL) for Kurunegala district was Rs. 2851 for month of May 2008. Proportion of food expenditure per month according to Colombo Consumer Price Index is (CCPI) 46.71\% (Central Bank Report, 2008).

To develop the indices representing Health, Asset and Education, the "Principal Component Analysis" was performed separately for each set of indicators. The Principal Components which have Eigen value greater than one were selected to construct the indices. To estimate the index, the weighted average of $n$ principal component (PC's) was taken, where the weights are the Eigen values $(\lambda)$ of the correlation matrix R. Thus the index can be represented as: 
$I=\frac{\lambda_{1} P_{1}+\lambda_{2} P_{2}+\ldots+\lambda_{n} P_{n}}{\lambda_{1}+\lambda_{2}+\ldots+\lambda_{n}}$

\section{Data Collection}

The primary data were collected from 150 paddy farmers and non-farmers in Kurunegala district who were selected using Multi-Stage Sampling techniques. There were eight out of 30 Divisional Secretariat (DS) divisions in the Kurunegala district, which have the highest number of paddy holdings and they were selected for data collection. Next, eight Grama Niladari (GN) divisions were selected randomly from each DS division followed by random selection of 1 or 2 villages from each GN division. Finally, 6 to 16 households, depending on the population, were selected from each village (Table 2). For the purpose of comparisons, same number of paddy farmers and nonfarmers were selected representing similar income group (Rs. 10,000 - 20,000 per month). After developing the aggregate indices for individuals, average indices for two communities were formulated by getting the average of individual aggregate indices. A face-to-face in depth interview was carried out from April to May 2009 with each respondent with the help of a structured questionnaire, which was pretested by using the responses from 10 paddy farmers and non-farmers. Those farmers whose main income received from paddy were named as "paddy farmers", whilst the main income received from nonagricultural activities (government workers, private workers and business man) were named as "non-farmers"

\section{RESULTS AND DISCUSSION}

\section{Summary Statistics of Health Indicators}

The average per head health expenditure for both communities was around Rs.290.00 per month. Further, it was revealed that $46.67 \%$ of the farmers were spending low proportion of money for their food than due proportion of food expenditure per month.

\section{Health Index}

The values obtained for the Health Index in comparison with paddy farmers and nonfarmers are illustrated in Figure 1. It was revealed that paddy farmers' health index was lower than that of non-farmers. In general, Non-farmer average Health Index (AVG-NFHI) score was 0.785 , while the paddy farmers' average Health Index (AVG-FHI) score was 0.195. There was a substantial difference in the value of $\mathrm{HI}$ between paddy farmers and non-farmers community although their level of income fell into the same category (Rs. 10,000 20,000).

\section{Summary Statistics of Asset Indicators}

The standards of living of a population which adds up to its welfare status are indicated by access to assets such as Television, Computers, Telephones, Mobile phones etc. The non-farmer community has a higher purchasing power for selected assets and corresponding penetration for the farmer community was much lower (Figure 2). Abbreviations used in the Figure 1 are given in the Table 1 under the household own assets. 
Table 2. Allocation of sampling units

\begin{tabular}{lllc}
\hline \multicolumn{1}{c}{ DS Division } & \multicolumn{1}{c}{ GN Division } & \multicolumn{1}{c}{ Village } & Number of households \\
\hline Polpithigama & Ihala Thelambiyawe & Thelambiyawe & 16 \\
Ibbagamuwa & Doluwa & Doluwa & 16 \\
Panduwasnuwara & Bandara Koswatte & Bandara Koswatte & 12 \\
Maho & Balagollagama, & Amunakole & 10 \\
& Panwewe & Panwewe & 6 \\
Galgamuwa & Kokwewe & Makalanegama & 12 \\
Rideegama & Kavisigamuwe & Kavisigamuwe & 8 \\
Wariyapola & Nelliya & Nelliya & 6 \\
& Minuwangete & Minuuwangete & 6 \\
Pannala & Makandura & Makandura & 8 \\
\hline
\end{tabular}

Table 3. Comparison of the health indicators

\begin{tabular}{|c|c|c|}
\hline Health indicators & Farmer (\%) & Non-farmer (\%) \\
\hline \multicolumn{3}{|l|}{ - $\quad$ Chronic disease (CD) } \\
\hline Yes & 20 & 10 \\
\hline No & 30 & 20 \\
\hline Not checked for last 6 months & 50 & 70 \\
\hline \multicolumn{3}{|l|}{ - $\quad$ Number of chronic disease (NCD) } \\
\hline One & 13.33 & 6.8 \\
\hline Two & 5.67 & 3.2 \\
\hline More than two & 4.5 & 2.6 \\
\hline None & 76.5 & 86.4 \\
\hline \multicolumn{3}{|l|}{ - $\quad$ Frequency of getting illnesses per month (FGI) } \\
\hline Once & 56.2 & 89.1 \\
\hline Twice & 36.3 & 8.3 \\
\hline More than twice & 7.5 & 2.7 \\
\hline \multicolumn{3}{|l|}{ - $\quad$ Getting reliable health service (RHS) } \\
\hline Government doctors & 60 & 56.67 \\
\hline Rural hospital doctors & 33.33 & 40 \\
\hline Medical assistants & 0 & 3.3 \\
\hline Others & 6.67 & 0 \\
\hline \multicolumn{3}{|l|}{ - $\quad$ Problems assessing health service $(\mathrm{PH})$} \\
\hline No problem & 20 & 36.67 \\
\hline One problem & 30 & 36.67 \\
\hline Two problems & 40 & 20 \\
\hline Three problems & 6.67 & 3.33 \\
\hline More than three problems & 3.33 & 3.33 \\
\hline $\begin{array}{l}\text { - Monthly expenditure for food \& nonalcoholic beverages \% } \\
\text { of people less than PL (EFB) }\end{array}$ & 46.67 & 20 \\
\hline \multicolumn{3}{|l|}{ - $\quad$ Access to safe drinking water (AW) } \\
\hline Government tap line & 13.33 & 10 \\
\hline Own well & 76.67 & 80 \\
\hline Common well & 10 & 10 \\
\hline - $\quad$ Average per head health expenditure (HE) & 290.138 & 290.69 \\
\hline
\end{tabular}




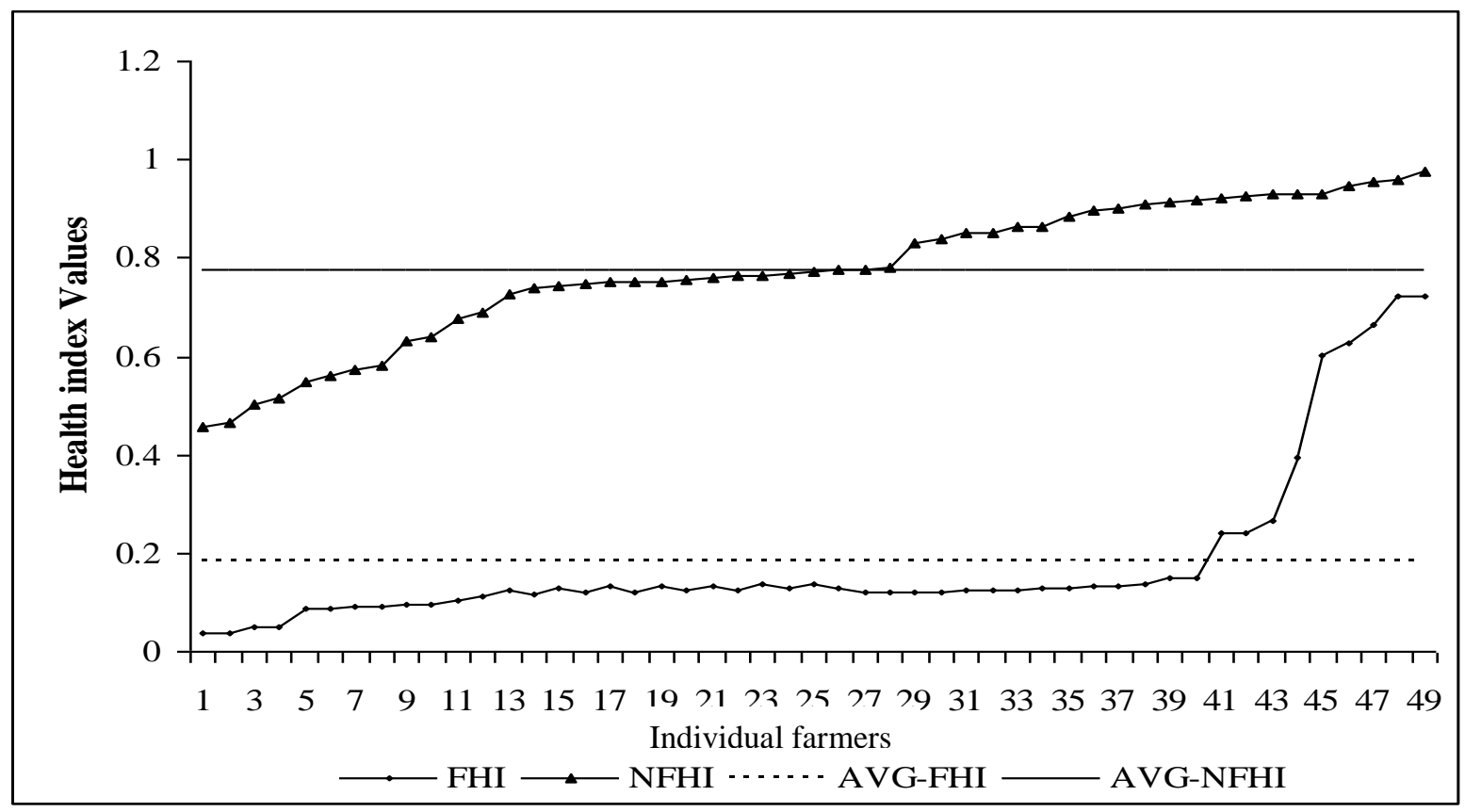

FHI: Paddy Famer Health Index, NFHI: Non-farmer Health Index, AVG-FHI: Average Paddy Farmer Health Index, AVG-NFHI: Average Non-farmer Health Index,

Figure 1. Individual health indices between communities

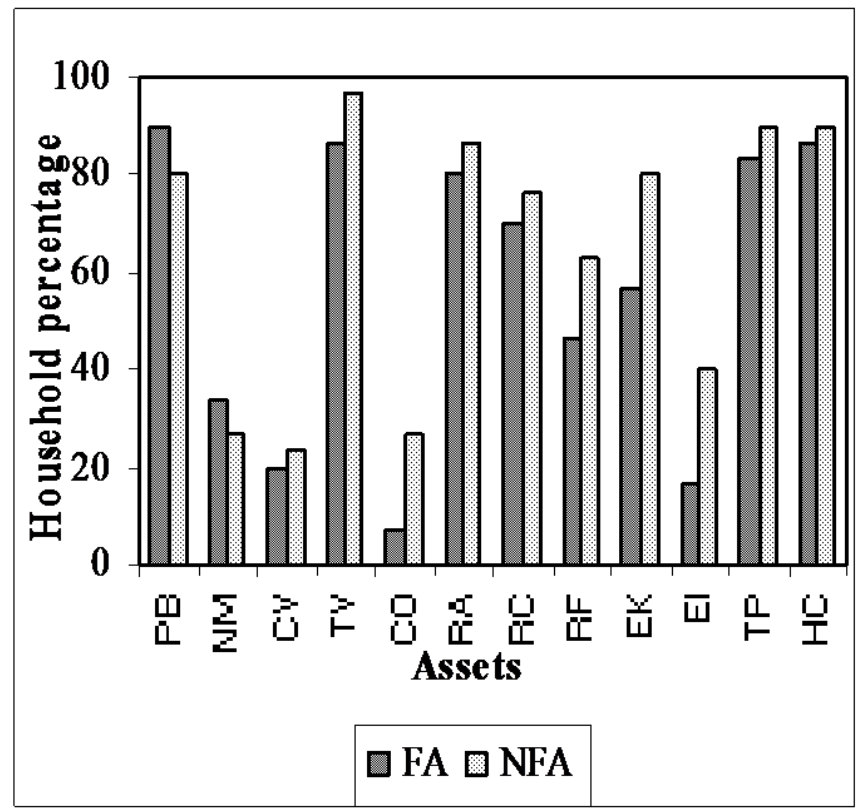

Figure 2. Ownership information of selected goods and services in terms of farmer average (FA) and Non Farmer Average (NFA) 


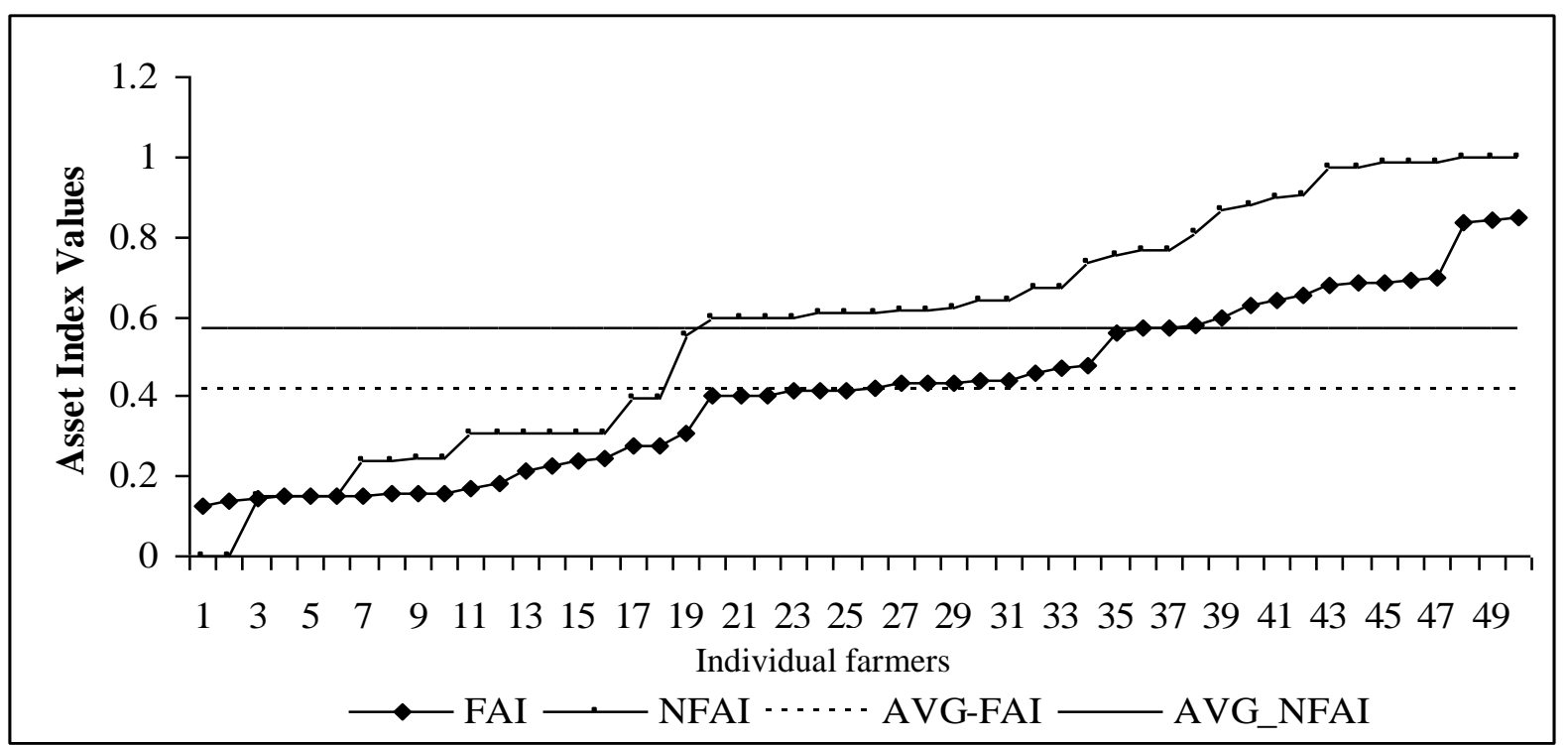

NFAI: Non-farmer Asset Index, FAI: Paddy farmer Asset Index

AVG_FAI: Average Non-farmer Asset Index, AVG_FAI: Average Paddy farmer Asset Index

Figure 2. Individual asset indices between two communities

\section{Asset Index}

The non-farmer average Asset Index (NFAI) scored a high value (0.603) compared to the paddy farmer average Asset Index (FAI) of 0.401. This indicates that most farmers have negative attitude towards acquiring the modern assets than those in the non-farmer community, in general (Figure 2).

\begin{abstract}
Summary Statistics of Education Indicators

Education status is another important factor to measure the level of development of a community. Comparison of education indicators between paddy farmer and nonfarmer communities are given in Table 4.
\end{abstract}

Table 4. Comparison of the education indicators between paddy farmer and non-farmer communities

\begin{tabular}{lll}
\hline Education Indicator & Farmer Community (\%) & Non-farmer Community (\%) \\
\hline $\begin{array}{l}\text { Farmer education } \\
\text { Passed A/L }\end{array}$ & 15.4 & \\
Passed O/L & 30.5 & 53.3 \\
$\quad \begin{array}{l}\text { Passed Grade Ten } \\
\text { Passed Grade Five }\end{array}$ & 20.5 & 10.7 \\
& 33.6 & 6 \\
$\begin{array}{l}\text { Per head expenditure on } \\
\text { education (Rs.) }\end{array}$ & 2168.33 & 2797.5 \\
\hline
\end{tabular}


In non-farmer community $53.33 \%$ of respondents passed Advance Level, which was much higher compared to paddy farmer community of $16.67 \%$. Average per head expenditure on education was Rs.2797.50 and 2168.33 respectively for the non-farmer community and paddy farmer community per month. development by selected criteria. The outcome of this analysis provides important information related to disparities of different communities with regard to their Health, Asset and Education. It highlights that the values of three indices obtained for paddy farmers are generally lower than those of non-farmers in Kurunegala district.

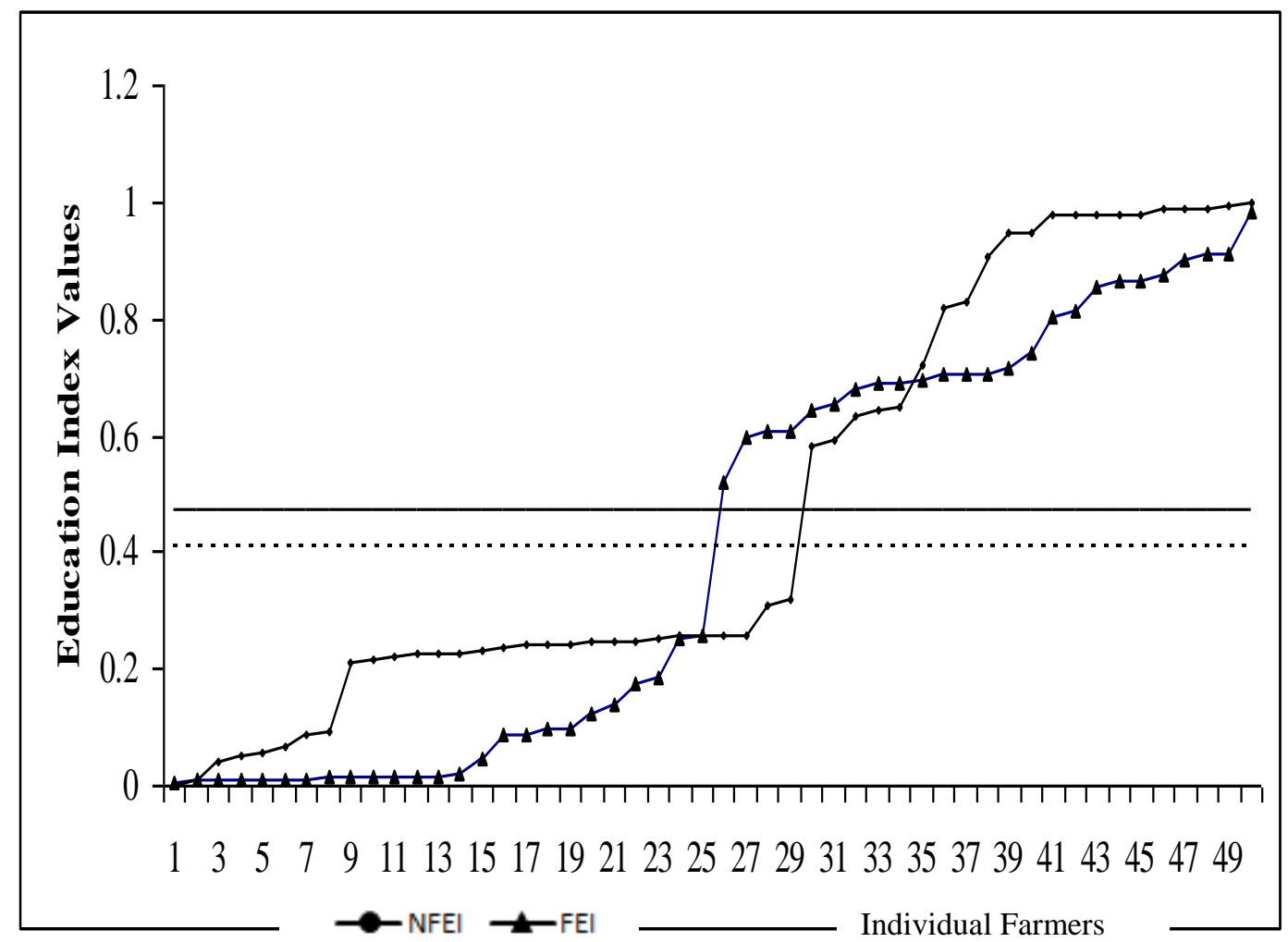

Figure 3. Individual education Indices between two communities

\section{Education Index}

When comparing the scoring pattern pertaining to the Education Index (Figure 3), Non-farmer Education Index (NFEI) recorded a higher score $(0.445)$ than the Paddy Farmer Education Index (FEI) of 0.401 .

\section{CONCLUSION}

This study illustrates the development of aggregate indices using multivariate techniques to assess the level of human
The findings based on the indices can be used by the government and policy makers as baseline information to develop programs to uplift the farmers' living standards.

\section{REFERENCES}

Adhikarinayake, T.B. (2005). Methodological design process to improve income from paddy farmers in Sri Lanka. Thesis, Wageningen University. 
Ghosh, P.K., Kundu, A. and Shariff, A. (2002). Indexing human development in India indicators, scaling and composition research working paper No.83, National Council of Applied Economic Research, New Delhi.4-25

Central Bank Annual Report (2008). Central Bank of Sri Lanka, Colombo 01.

Department of Census and Statistics. (2008). Available at http://www.statistics.gov.lk/agricult ure/paddy\%20statistics/ (Accessed 27 May 2009).

Department of Census and Statistics. (2002). Available at http://www.statistics.gov.lk/agricult ure/paddy\%20statistics (Accessed 27 May 2009).

Districts Secretariat-Kurunegala (2008). Available from http://www.ds.gov.lk/dist_kuruneg ala/english/admin3.php. (Accessed 2 July).

Kakar, P. and Shukla, R. (2006). Role of science \& technology higher education and research in regional socio- economic development. Working paper, National Council of Applied Economic Research, New Delhi.4-25 